\title{
Detection of HIV p17 antigen in lymphocytes but not epithelial cells from cervicovaginal secretions of women seropositive for HIV: implications for heterosexual transmission of the virus
}

\author{
PHILIPPE VAN De PERRE,* ANDRE De CLERCQ, \\ JACQUELINE COGNIAUX-LECLERC, $\ddagger$ DIDACE NZARAMBA,* \\ JEAN-PAUL BUTZLER,§ SUZY SPRECHER-GOLDBERGER
}

From the *AIDS Project, Kigali, Rwanda; †Department of Gynaecology, Centre Hospitalier de Kigali, Kigali, Rwanda; $\ddagger$ Institut Pasteur du Brabant, Brussels, Belgium; and §Laboratory of Microbiology, Saint-Pierre University Hospital, Brussels, Belgium

SUMMARY Human immunodeficiency virus (HIV) has been isolated from cervicovaginal secretions from infected women and is thought to be cell associated. To identify which cells harbour viral antigen, we used monoclonal antibodies to OKT4 and a monoclonal antibody directed against HIV p17 core antigen to perform indirect immunofluorescence assays of genital secretions from 17 HIV seropositive and 17 HIV seronegative women with leucorrhoea. OKT4 positive lymphocytes were detected in all tested samples. HIV p17 antigen was detected in the genital fluid lymphocytes in nine out of 14 seropositive subjects from whom lymphocytes were available. No viral antigen was detected in genital fluid lymphocytes of seronegative subjects, nor in any cervicovaginal epithelial cells. This study shows that lymphocytes are the major source of HIV in cervicovaginal secretions of infected women. Conditions that increase the lymphocyte population in the female genital tract, such as sexually transmitted disease (STD), chronic inflammation of the cervix, and menstruation, may facilitate the transmission of HIV during sexual intercourse.

Evidence for the heterosexual transmission of the human immunodeficiency virus (HIV), the retrovirus that causes the acquired immune deficiency syndrome (AIDS), ${ }^{12}$ has been a subject of considerable debate. Although the transmission of HIV from men to women has been clearly shown by epidemiological studies, ${ }^{34}$ transmission from women to men is still controversial. Some studies suggest its existence in both central Africa ${ }^{56}$ and the Western world, ${ }^{78}$ whereas others show little transmission even after repeated sexual contacts with virus carriers. ${ }^{9}$ HIV has been isolated from the vaginal and cervical fluid of HIV carriers. ${ }^{1011}$ Those studies, however, did not elucidate which cells in the female genital secretions act as a target for or a reservoir of the retrovirus. The

Address for reprints: S Sprecher-Goldberger, Institut Pasteur du Brabant, Laboratory of Virology, 642 rue Engeland, 1180-"russels, Belgium

Accepted for publication 9 August 1987 present study was undertaken to attempt detection of HIV antigen on cervicovaginal epithelial cells and lymphocytes found in cervical secretions of HIV seropositive and seronegative women presenting with leucorrhoea.

\section{Patients and methods}

PATIENTS AND SEROLOGICAL METHODS

We studied 17 consecutive African women seropositive for HIV (by an immunoenzyme test) who attended the department of gynaecology of the Centre Hospitalier de Kigali, Kigali, Rwanda, because they had leucorrhoea. They were compared with 17 consecutive seronegative patients of the same geographic origin attending the same department for the same reason. Standard gynaecological examination and sampling was performed by one of us (AdeC). None of the women was examined while she was menstruating. A coded serum sample was sent to the laboratory to confirm the detection of antibodies to HIV by 
repeat immunoenzyme assays (EIA, Vironostika, Organon Teknika, Boxtel, Netherlands) and indirect immunofluorescence. ${ }^{12}$ All results were further confirmed by either radioimmunoprecipitation (RIPA) or western blot, in which banding patterns were compared with those of serum known to be positive. ${ }^{1}$ All laboratory investigations were blind.

\section{VAGINAL AND EXOCERVICAL SECRETION \\ SAMPLES}

To obtain the maximum amount of fluid (more than $0.5 \mathrm{ml}$ ) vaginal and exocervical secretions were obtained by means of a wooden Ayre spatula and two or more sterile cotton swabs. The cotton swabs and spatula were placed in a sterile tube containing $3 \mathrm{ml}$ phosphate buffered saline (PBS), coded, and sent immediately to the laboratory. Specimens were processed within 30 minutes after collection. Secretions were suspended by expressing the cotton swabs on the side of the tube and by shaking the wooden spatula in the solution. The cells were then pelletted by low

Table 1 Demographic data, gynaecological findings, and HIV antibody in 34 African patients presenting with leucorrhoea

\begin{tabular}{|c|c|c|}
\hline Case No & Age (years) & Gynaecological findings \\
\hline \multicolumn{3}{|c|}{$H I V$ seropositive patients } \\
\hline 1 & 22 & Chancroid \\
\hline 2 & 38 & PID, SI \\
\hline 3 & 36 & Relapsing genital herpes, PID \\
\hline 4 & 29 & PID \\
\hline 5 & 26 & Gonococcal cervicitis \\
\hline 6 & 21 & PID, trichomonal cervicitis, SI \\
\hline 7 & 28 & PID \\
\hline 8 & 36 & PID \\
\hline 9 & 28 & PID, SI \\
\hline 10 & 35 & Relapsing genital herpes, PI, PID \\
\hline 11 & 21 & Condyloma acuminata, pregnancy \\
\hline 12 & 26 & Relapsing genital herpes \\
\hline 13 & 26 & PID \\
\hline 14 & 30 & $\begin{array}{l}\text { Mixed gonococcal and trichomonal } \\
\text { cervicitis }\end{array}$ \\
\hline 15 & 24 & Vaginal candidiasis \\
\hline 16 & 28 & Nil \\
\hline 17 & 28 & Vaginal candidiasis \\
\hline \multicolumn{3}{|c|}{ HIV seronegative patients } \\
\hline 18 & 30 & Vaginal candidiasis, SI \\
\hline 19 & 35 & Vaginal candidiasis \\
\hline 20 & 26 & PID \\
\hline 21 & 34 & Pregnancy \\
\hline 22 & 18 & Nil \\
\hline 23 & 22 & Genital herpes, gonococcal cervicitis \\
\hline 24 & 31 & PID \\
\hline 25 & 23 & PID \\
\hline 26 & 36 & Nil \\
\hline 27 & 24 & Nil \\
\hline 28 & 30 & Relapsing genital herpes \\
\hline 29 & 28 & Nil \\
\hline 30 & 32 & Nil \\
\hline 31 & 27 & PID, SI \\
\hline 32 & 38 & Chancroid \\
\hline 33 & 29 & Vaginal candidiasis \\
\hline 34 & 36 & Nil \\
\hline
\end{tabular}

PID = pelvic inflammatory disease; $\mathrm{PI}=$ primary infertility; $\mathrm{SI}=$ speed centrifugation, resuspended, and mononuclear cells were separated in Ficoll-Hipaque. This procedure yielded at least 600 lymphocytes a specimen in $27 / 34$ genital fluid samples. Lymphocytes and vaginal and exocervical cells collected from the pellet were washed four times in PBS.

An aliquot of lymphocyte enriched suspension was used to count $T$ helper (inducer) cells by indirect immunofluorescence using monoclonal antibodies (OKT4; Ortho Diagnostic System, Raritan, New Jersey, USA). Aliquots of lymphocyte enriched suspension and of the vaginal and exocervical epithelial cells were used to detect HIV p17 core antigen by indirect immunofluorescence. The monoclonal antibody used (8A6A7C5) was prepared and fully characterised by one of us (JCL). Briefly, cells (from the lymphocyte enriched fraction and from the pellet) were washed four times in PBS, prepared with glass slides (Bio Merieux), air dried, and then fixed in acetone for 10 minutes at $-20^{\circ} \mathrm{C}$ under agitation. Slides were then incubated for one hour at room temperature with the HIV p17 monoclonal antibody diluted 1:2. After washing, the slides were incubated for one hour at room temperature with a polyvalent goat anti-mouse IgG-FITC (fluorescein isothiocyanate) immunoglobulin (Tago, Burlingame, California, USA) diluted 1:40, washed, and air dried. The percentage of lymphocytes or cervicovaginal epithelial cells showing cytoplasmic fluorescence was then estimated with a fluorescence microscope (Laborlux 11 Leitz microscope). Control experiments were also performed on similar lymphocyte samples treated with PBS instead of HIV p17 monoclonal antibody.

\section{Results}

DEMOGRA PHIC, CLINICAL, AND SEROLOGICAL DATA

All 34 patients were African women presenting with leucorrhoea. Table 1 summarises the demographic data and clinical findings on gynaecological examination of the 34 women. In six (cases 5, 6, 10, 13, 17, and 22), scraping of the cervix provoked minor bleeding from erosions of the cervix, probably due to active cervicitis.

Of the 34 patients, 17 had detectable antibodies against HIV by repeated EIA, indirect immunofluorescence, and radioimmunoprecipitation or western blot. Sixteen of these women had active genital infections at the time the samples were collected. Of the 17 seropositive women, seven (cases 1, 7, 8, 9, 10,13 , and 16) had histories of repeated sexually transmitted disease (STD) in the previous two years, and one (case 3 ) had received a blood transfusion in Africa 18 months before the study began. This latter 
Table 2 OKT4 and HIV p17 on lymphocytes and epithelial cells from cervicovaginal fluid samples of 34 women with or without antibodies to HIV

\begin{tabular}{|c|c|c|c|c|c|c|c|}
\hline \multirow{2}{*}{\multicolumn{2}{|c|}{$\begin{array}{c}\text { Patients } \\
\text { status) }\end{array}$}} & \multicolumn{5}{|l|}{ Lymphocytes } & \multirow{2}{*}{$\begin{array}{l}\text { Epithelial cells } \\
\text { No of patients } \\
\text { HIV p17 positive }\end{array}$} \\
\hline & & $\begin{array}{l}\text { No of patients } \\
\text { OKT4 positive }\end{array}$ & $\begin{array}{l}\text { Mean }(S D) \% \\
\text { OKT4 positivity }\end{array}$ & $\begin{array}{l}\text { No of patients } \\
\text { HIV p } 17 \text { positive }\end{array}$ & $\begin{array}{l}\% \text { Lymphocytes } \\
\text { HIV pI7 positive }\end{array}$ & $\begin{array}{l}\text { No of patients } \\
\text { PBS positive (controls) }\end{array}$ & \\
\hline $\begin{array}{l}\text { Seropositive } \\
\text { Seronegative }\end{array}$ & $\begin{array}{l}(\mathrm{n}=17) \\
(\mathrm{n}=17)\end{array}$ & $\begin{array}{l}17 / 17 \\
17 / 17\end{array}$ & $\begin{array}{l}22(11)^{*} \\
36(12)^{*}\end{array}$ & $\begin{array}{l}9 / 14 \dagger \\
0 / 13 \dagger\end{array}$ & $\begin{array}{l}0.02-0.5 \\
0\end{array}$ & $\begin{array}{l}0 \\
0\end{array}$ & $\begin{array}{l}0 / 17 \\
0 / 17\end{array}$ \\
\hline
\end{tabular}

patient and case 13 presented with severe weight loss and generalised lymphadenopathy. Of the 17 seronegative women, 10 had active genital infections and one was pregnant (in the third trimester). Gynaecological examination of the other six failed to detect any abnormalities or signs of pregnancy. One seronegative patient (case 28) had a history of multiple STDs in the previous two years and had experienced moderate weight loss and generalised lymphadenopathy.

\section{OKT4 AND HIV PI7 MARKERS ON \\ LYMPHOCYTES AND EPITHELIAL CELLS FROM CERVICOVAGINAL FLUID}

Table 2 shows the detection of OKT4 and HIV p17 on lymphocytes and epithelial cells from cervicovaginal fluid samples of the 34 patients. OKT4 positive lymphocytes were detected in genital secretions from all women tested. Higher proportions were, however, found in seronegative women (mean $36 \%$ (SD 12\%), individual data not shown) than seropositive women $(22 \%(11 \%))(t$ test, $\mathrm{p}=0 \cdot 01)$. Of 14 seropositive patients from whom vaginal fluid lymphocytes were available, nine had $0.02 \%$ to $0.5 \%$ of lymphocytes reactive with HIV p17 monoclonal antibodies. In contrast, of the 13 seronegative women from whom vaginal fluid lymphocytes were available, none showed staining for this antigen $\left(\chi^{2} 4 \cdot 4 ; p<\right.$ 0.05 ). None of the cervicovaginal lymphocyte cell samples from either group of patients showed evidence of cytoplasmic fluorescence, and no fluorescence was detected in the samples treated with PBS instead of HIV p17 monoclonal antibody.

\section{Discussion}

The findings from this study provide laboratory data that support the epidemiological evidence for bidirectional heterosexual transmission of HIV.

One of the major properties of HIV is now known to be its tropism for T lymphocytes bearing the CD4 (T4) antigen. This particular lymphotropism has been shown to be based on the binding of envelope glycoproteins of the retrovirus with the T4 molecule itself. ${ }^{1314}$ The fact that OKT4 positive lymphocytes can be found in the genital secretions of women with and without genital infection has considerable implications, as potential target cells of HIV in the female genital tract are essential to explain male to female sexual transmission of HIV.

HIV has been isolated in various body fluids, including vaginal and cervical secretions, from symptomatic and asymptomatic carriers of the virus. ${ }^{1011}$ Those studies, however, were of female carriers of HIV, only a few of whom experienced concomittent genital infections. HIV was recovered only after several transfers on fresh peripheral blood mononuclear cells, which indicated that little HIV was present. Filtering the vaginal fluid considerably reduced the rate of virus isolation, which suggested that most HIV particles are cell associated in vaginal secretions. Those studies did not, however, show which type of cell in the female genital tract could harbour the retrovirus.

The present study describes an indirect immunofluorescence technique to detect cell related HIV p17 antigen in cervicovaginal fluid. A similar technique has recently been shown to be effective in showing HIV p15 and p24 antigens on fresh corneal cells obtained from a touch preparation. ${ }^{15}$ Monoclonal antibodies directed against the HIV gag precursor have also been shown, by an immunohistochemical method, to label dendritic reticular cells of infected patients (Chassagne $\mathrm{J}$, et al, unpublished observation). The sensitivity of these techniques, however, remains to be evaluated in comparison with virus isolation.

Our results show that HIV p17 is present in the lymphocytes from genital secretions of seropositive, but not seronegative, patients. The percentage of lymphocytes in genital secretions that reacted with the monoclonal antibody to HIV p17 (from $0.02 \%$ to $0.5 \%$ ) was higher than that in uncultured peripheral blood lymphocytes of infected patients $(0.01 \%, S$ Sprecher-Goldberger, unpublished data). The reason for this difference is not known, but could be attributable to local chronic inflammation and lymphocyte activation resulting from the genital infection present in our subjects.

Two of the nine subjects with positive HIV p17 
staining had minimal bleeding from the cervix at the time of scraping (a common event when the cervix is rendered friable by chronic cervicitis), thus increasing the number of lymphocytes in their genital secretions. The introduction of blood in these specimens cannot be thought to be disturbing when searching for infected cells, as it simulates menstruation and the traumatic (such as post-coital) bleeding often reported by patients with chronic cervicitis.

The lack of HIV p17 staining of cervicovaginal epithelial cells suggests that, though the integrity of the mucosa may be an important factor in HIV transmission, epithelial cells do not themselves act as targets or reservoirs for the retrovirus. Hybridisation assays using HIV deoxyribonucleic acid (DNA) probes should, however, be performed before excluding cervicovaginal epithelial cells as a potential reservoir for HIV.

Genital infections, contact bleeding from the cervix, and menstruation unquestionably increase the number of lymphocytes in the female genital tract. The fact that lymphocytes can behave as potential target cells and as reservoirs for HIV in female genital fluid has important ramifications for our understanding of transmission, both from men to women and from women to men. The strong association between past or present STDs and infection with HIV in prostitutes and their clients has been emphasised by epidemiological studies performed in eastern and central Africa. ${ }^{16} 17$ Thus both laboratory and epidemiological studies support STDs as an enhancing factor in the heterosexual transmission of HIV. This could partly explain the relative lack of sexual transmission reported in the United States of America and Australia in non-promiscuous people. ${ }^{79}$

This study shows that lymphocytes are a target for and source of HIV in the female genital tract and suggest that STDs could be an enhancing factor in the bidirectional heterosexual transmission of AIDS.

We thank Dr C Bizimungu, Minister of Health of Rwanda, the members of the Rwandese National Commission on AIDS, Professors L Thiry, S Hulley, and A Meheus, and Drs $\mathrm{P}$ De Mol and S Allen for their help and criticism, and Mrs C Thiriart for performing the HIV RIPA tests.
This study was supported by a grant from the Belgian Ministry for Cooperation in Development.

\section{References}

1 Barré-Sinoussi F, Cherman JC, Rey F, et al. Isolation of a Tlymphotropic retrovirus from a patient at risk for acquired immune deficiency syndrome (AIDS). Science 1983; 220: 868-71.

2 Gallo RC, Shearer GM, Kaplan M, et al. Frequent detection and isolation of cytopathic retrovirus (HTLV-III) from patients with AIDS and at risk for AIDS. Science 1984;224:500-3.

3 Harris C, Small CB, Klein RS, et al. Immunodeficiency in female sexual partners of men with the acquired immunodeficiency syndrome. N Engl J Med 1983;308:1181-4.

4 Redfield RR, Markham PD, Salahuddin SZ, et al. Frequent transmission of HTLV-III among spouses of patients with AIDS-related complex and AIDS. JAMA 1985;253:1571-3.

5 Van de Perre P, Clumeck N, Carael M, et al. Female prostitutes: a risk group for infection with human T-cell lymphotropic virus type III. Lancet 1985; ii:524-6.

6 Clumeck N, Van de Perre PM, Carael M, Rouvroy D, Nzaramba D. Heterosexual promiscuity among African patients with AIDS. N Engl J Med 1985;313:182.

7 Centers for Disease Control. Heterosexual transmission of human T-lymphotropic virus type III/lymphadenopathy associated virus. $M M W R$ 1985;34:561-3.

8 Centers for Disease Control. Update: acquired immunodeficiency syndrome (AIDS) - United States. MMWR 1984;33:661-4.

9 Stewart GJ, Tyler JPP, Cunningham AL, et al. Transmission of human T-cell lymphotropic virus type III (HTLV-III) by artificial insemination by donor. Lancet 1985;ii:581-5.

10 Vogt MW, Witt DJ, Craven DE, et al. Isolation of HTLVIII/LAV from cervical secretions of women at risk for AIDS. Lancet 1986;i:525-7.

11 Wofsy CB, Cohen JB, Hauer LB, et al. Isolation of AIDSassociated retrovirus from genital secretions of women with antibodies to the virus. Lancet 1986;i:527-9.

12 Cheingsong-Popov R, Weiss RA, Dalgleish A, et al. Prevalence of antibody to human T-lymphotropic virus type III in AIDS and AIDS-risk patients in Britain. Lancet 1984;ii:477-80.

13 Dalgleish AG, Beverly PCL, Clapham PR, Crawford DH, Greaves MR, Weiss RA. The CD4 (T4) antigen is an essential component of the receptor for the AIDS retrovirus. Nature 1984;312:763-7.

14 Klatzman D, Champagne E, Chamaret S, et al. T-lymphocyte T4 molecule behaves as the receptor for human retrovirus LAV. Nature 1984;312:767-8.

15 Salahuddin SZ, Palestine AG, Heck E, et al. Isolation of the human T-cell leukemia/lymphotropic virus type III from the cornea. Am J Ophthalmol 1986;101:149-52.

16 Kreiss JK, Koech D. Plummer FA, et al. AIDS virus infection in Nairobi prostitutes. Spread of the epidemic to East Africa. $N$ Engl J Med 1986;314:414-8.

17 Van de Perre P, Clumeck N, Steens M, et al. Seroepidemiological study on sexually transmitted diseases and hepatitis $B$ in African promiscuous heterosexuals in relation to HTLV-III infection. European Journal of Epidemiology 1987;3:14-8. 